\title{
Tracheal Bronchus; A Computed Tomography Study
}

\author{
Trakeal Bronkus; Bilgisayarlı Tomografi Çalışması
}

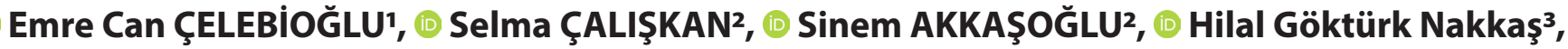 (D) Ibrahim Tanzer SANCAK ${ }^{4}$}

\author{
'Department of Radiology, Faculty of Medicine, Ankara University, Ankara, Turkey \\ 2Department of Anatomy, Faculty of Medicine, Ankara Yıldırım Beyazıt University, Ankara, Turkey \\ 3 Department of Histology and Embryology, Faculty of Medicine, Ankara Yıldırım Beyazıt University, Ankara, Turkey \\ ${ }^{4}$ Department of Radiology, Faculty of Medicine, TOBB University, Ankara, Turkey
}

\begin{abstract}
Aim: The aim of the study recognize and classify the Tracheal Bronchus (TB) in our population.

Material and Method: A total of 1500 patients who underwent thoracic Computed Tomography (CT) examination for different reasons were enrolled in this retrospective study. 12 patients with TB were reported. Of the 12 patients with TB; five were males and seven were females. Prevalence of TB was found to be $0.8 \%$. It was indicated more frequently in women (58.3\%) than in men (41.7\%).

Results: Of the 12 patients with TB seven had displaced type (58.3\%), two had supernumerary type (16.7\%) and three had pig bronchus (25\%). Displaced type was most common among the females. Of the five males two had displaced type, two had pig bronchus and one had supernumerary type. Relation between gender and type was not found to be statistically significant $(p=0.516)$. The mean diameter of the TB was $5.24 \pm 1.53 \mathrm{~mm}$. Difference between displaced and pig bronchus types according to diameter is statistically significant $(\mathrm{p}=0.017$ ). Distance between carina and TB was also measured in the present study. There was no difference between displaced type and pig bronchus type according to distance from carina $(\mathrm{p}=0.067)$.
\end{abstract}

Conclusion: Recognizing the TB is critically important during endotracheal intubation. When the TB is occluded by the side of the tube the lobe may collapse. On the other hand when it is mistakenly intubated, over aeration may lead pneumothorax.

Keywords: Tracheal bronchus, pig bronchus, supernumerary tracheal bronchus, displaced tracheal bronchus
Öz

Amaç: Bu çalışmanın amacı, popülasyonumuzdaki Trakeal Bronkusları (TB) tespit etmek ve sınıflandırmaktır.

Gereç ve Yöntem: Bu retrospektif çalışmaya farklı nedenlerle torasik BT çektiren toplam 1500 hasta dahil edildi. 12 bireyde TB tespit edildi. TB'li 12 hastanın; beşi erkek, yedisi kadındı. TB prevalansı \%0,8 bulundu. Kadınlarda (\% 58,3) erkeklerden (\% 41,7) daha sık tespit edildi.

Bulgular: TB'lu 12 bireyin yedisinde displaced tip (\% 58.3), ikisinde supernumarary tip (\% 16.7) ve üçünde pig tip (\% 25) bronkus vardı. Displaced tip kadınlar arasında en yaygın olanıdıydı. Beş erkekten ikisinde displaced tip, ikisinde pig tip, birinde supernumerary tip görüldü. Cinsiyet ve tip arasındaki ilişki istatistiksel olarak anlamlı bulunmadı ( $p=0.516$ ). TB'nin ortalama çapı $5.24 \pm 1.53 \mathrm{~mm}$ idi. Displaced ve pig bronkus tipleri arasındaki çapa göre fark istatistiksel olarak anlamlıydı ( $p=0,017)$. Bu çalışmada ayrıca carina ve TB arasındaki mesafe de ölçüldü. Displaced tip ile pig bronkus tiplerinin carina'ya olan mesafeleri açısından fark yoktu ( $p=0.067)$.

Sonuç: TB'nin tanınması endotrakeal entübasyonda kritik öneme sahiptir. TB, tüpün yan yüzü tarafından tıkandığında, lob kollapsa uğrayabilir. Diğer yandan, yanlışıkla entübe edildiğinde, aşıı havalanma sonucu pnömotoraks oluşabilir.

Anahtar Kelimeler: Tracheal bronkus, pig bronkus

Corresponding (illetişim): Emre Can ÇELEBIOĞLU, Department of Radiology, Faculty of Medicine, Ankara University, Ankara, Turkey E-mail (E-posta): emrecelebioglu@yahoo.com.tr 


\section{INTRODUCTION}

Tracheal bronchus (TB) is a congenital anomaly which is usually located at the junction of the mid and distal thirds of trachea on the right lateral wall. ${ }^{[1,2]}$ It originates from trachea or either from the main bronchus and it is directed to the upper lobe of the lung. ${ }^{[3]}$ Tracheal bronchii are commonly seen on the right side but can also be seen on the left side or rarely seen bilaterally. Vascular supply is typical. ${ }^{[4]}$ Anatomist Sandifort first described TB in 1785. It commonly originates about $2 \mathrm{~cm}$ above the carina while normal right upper lobe bronchus arises from $1-3 \mathrm{~cm}$ distal to the trachea. TB which arises $6 \mathrm{~cm}$ above carina has also been reported in the literature. ${ }^{[2,5-8]}$ It typically originates from lateral wall of trachea or from the main bronchus. ${ }^{[2,5]}$ Even if they originate from different parts of the airway tree its' direction is the upper lobe. ${ }^{[5]}$

There are three types of TB described; displaced type, supernumerary type and true 'pig' bronchus type. ${ }^{[2,8]}$ These subdivisions are based on the branching patterns of the right upper lobe bronchus. In the displaced type right upper lobe bronchus bifurcates and anomalous bronchus (apical segment) arises from trachea. In the supernumerary type trifurcation of normal right upper lobe bronchus is visible but there is an accessory bronchus arising from trachea. Entire right upper lobe bronchus is displaced to trachea from right main bronchus in the true bronchus type. ${ }^{[2,6]}$ Levin et al. ${ }^{[2]}$ reported the displaced type (18\%) to be the most common one. In the present study we aimed to recognize and classify the TB in our population.

\section{MATERIAL AND METHOD}

Ethics committee approval was received by Ankara Yıldırım Beyazıt University Education and Research Hospital Clinical Research Ethics Committee (Date: 11.09.2019, number: 92).

A total of 1500 patients who underwent thoracic CT examination for different reasons were enrolled in this retrospective study. Patients had no history of thoracic trauma or surgery. 12 patients with TB were reported.

The CT images of the cases were obtained from the archive system. CT examinations were obtained with Philips Ingenuity 128 slice computed tomography (CT device) device (Philips Medical Systems, Cleveland, OH, USA). Patient dose parameters were adjusted automatically for the lung parenchyma by the device. A $1 \mathrm{~mm}$ slice thickness and a pitch value of 1 were used at thorax CT scans. All thoracic CT scans include entire thoracic area to view tracheobronchial tree clearly. CT scans were made either with or without an intravenous contrast media. Axial reformat images (thickness of 2-3mm) were performed.

\section{Statistical Method}

Descriptive statistics were given as frequency and percent for categorical variables and mean (std.dev) values were used for continuous ones. To compare diameter and 'distance from carina' values between displaced and pig bronchus types, Mann-Whitney $\mathrm{U}$ test was used because both diameter and 'distance from carina' is not normal distributed within each group. Supernumerary type was not evaluated statistically because of insufficient sample size.

To evaluate the relation between gender and types, chi-square test statistics was used. Type-l error rate was taken as 0.05 to test statistical hypotheses.

SPSS 20.0 was used to run statistical analyses (IBM Corp. Released 2011. IBM SPSS Statistics for Windows, Version 20.0. Armonk, NY: IBM Corp.)

\section{RESULTS}

1500 patients who underwent CT imaging for various indications were enrolled in the present study. A total of 12 patients with TB were reported. Median age of patients was $49.67 \pm 13.30$ (range 27-75 years). Of the 12 patients with TB; five were males and seven were females. Prevalence of TB was found to be $0.8 \%$. It was found more frequently in women (58.3\%) than in men (41.7\%).

Of the 12 patients with TB seven had displaced type (58.3\%) (Figure 1), two had supernumerary type (16.7\%) (Figure 2) and three had pig bronchus (25\%) (Figure $\mathbf{3} \mathbf{a}, \mathbf{b}$ ). Displaced type was most common among the females. Of the five males two had displaced type, two had pig bronchus and one had supernumerary type. The relation between gender and type was not found to be statistically significant $(p=0.516)$ (Table 1).

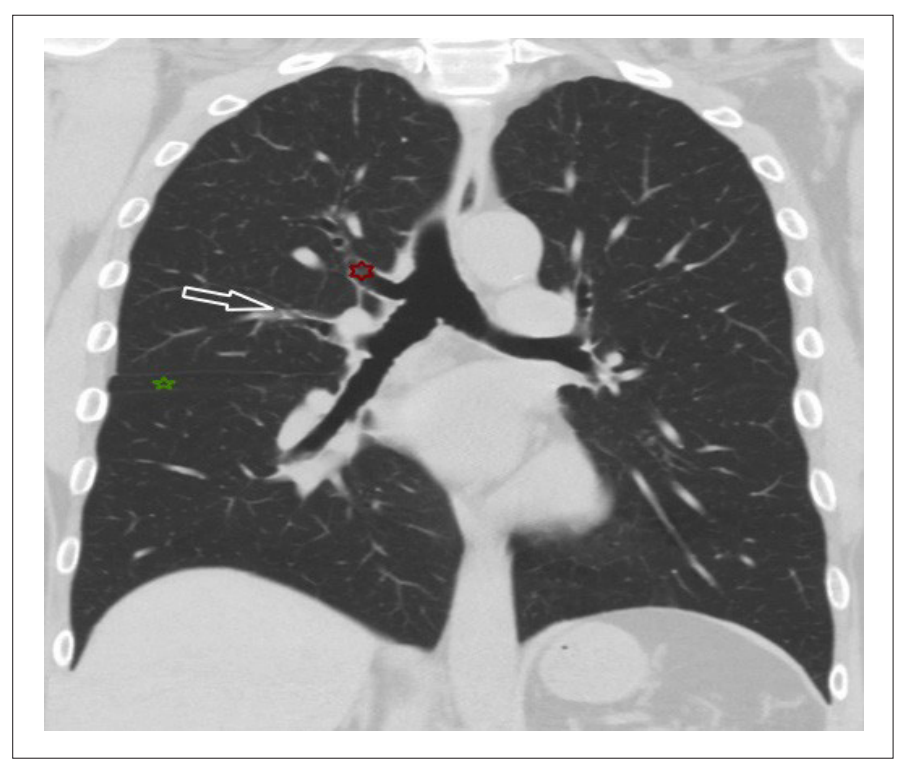

Figure 1. Displaced type TB on coronal image at a 58 years old male patient in a thorax CT. Red star: displaced apical segment bronchus, White arrow: Right upper lobe bronchus consists posterior and anterior segments. Green star: middle lobe. Horizontal and oblique fissures seen passing from the upper and lower border of the green star. 


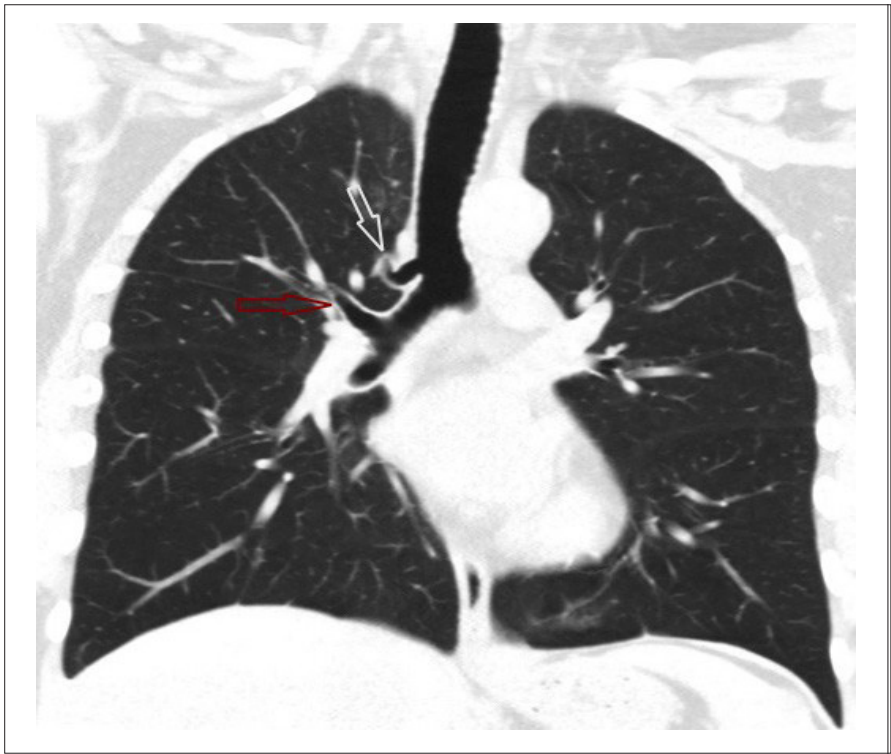

Figure 2. Supernumerary type TB seen in a thorax CT at lung window level (Coronal image). White arrow: atypic supernumerary upper lobe tracheal bronchus, red arrow: right upper lobe bronchus that consists the apical, posterior and anterior segments. Note: Middle lobe, horizontal and oblique fissures seen near back end of the red arrow.

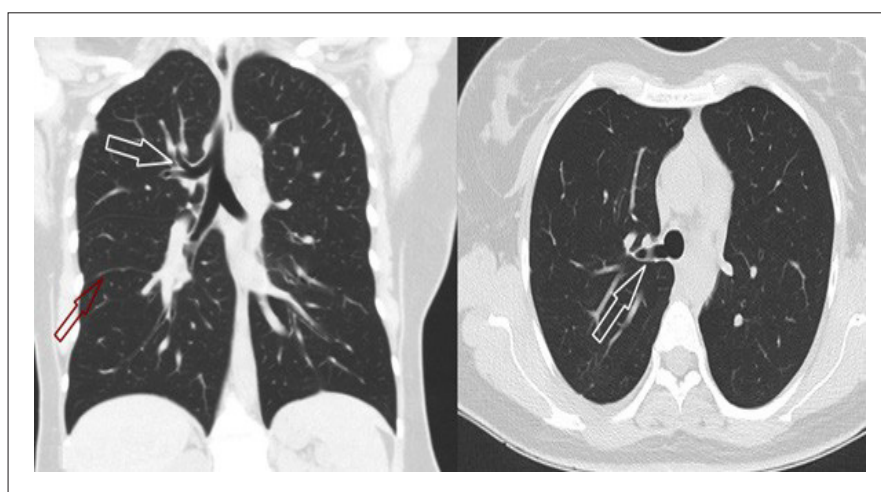

Figure 3 a,b. Pig bronchus seen in a 41 years old female patient on coronal and axial images. Right upper lobe bronchus bifurcating directly from trachea above carina whicht consists the apical, posterior and anterior segments shown on coronal and axial images with white arrows(same patient). Note: Oblique fissure shown with the red arrow.

\section{Table 1. Gender distrubition within each type}

Gender

types

total

Displaced supernumerary pig bronchus

\begin{tabular}{lcccc}
\hline Male & $2(28.6 \%)$ & $1(50 \%)$ & $2(66.7 \%)$ & $5(41.7 \%)$ \\
Female & $5(71.4 \%)$ & $1(50 \%)$ & $1(33.3 \%)$ & $7(58.3 \%)$ \\
Total & $7(58.3 \%)$ & $2(16.7 \%)$ & $3(25 \%)$ & $12(100 \%)$ \\
\hline
\end{tabular}

The mean diameter of the TB was $5.24 \pm 1.53 \mathrm{~mm}$ (range $2.17 .7 \mathrm{~mm}$ ). Mean diameter of pig bronchus was $7.1 \mathrm{~mm}$, of the displaced type was $5.3 \mathrm{~mm}$, of the supernumerary type was $2.8 \mathrm{~mm}$. Difference between displaced and pig bronchus types according to diameter is statistically significant $(p=0.017)$. Supernumerary type was not evaluated statistically in means of diameter because of insufficient sample size (Table $\mathbf{2}$ ).
Table 2. Comparing diameter and distance from carina within types

\begin{tabular}{lcc} 
Types & $\begin{array}{c}\text { Distance from carina }(\mathbf{m m}) \\
\text { Median }(\mathbf{m i n}-\mathbf{m a x})\end{array}$ & $\begin{array}{c}\text { Diameter }(\mathbf{m m}) \text { Median } \\
(\mathbf{m i n}-\mathbf{m a x})\end{array}$ \\
\hline Displaced & $6.1(3.1-11.9)$ & $5.3(4.3-5.9)$ \\
Pig bronchus & $11.20(9.8-21.8)$ & $7.1(6.4-7.7)$ \\
Supernumerary & $10.65(2.3-19)$ & $2.8(2.1-3.5)$ \\
\hline
\end{tabular}

Distance between carina and TB was also measured in the present study. The median distance between carina and pig bronchus was $11.20 \mathrm{~mm}$, between carina and supernumerary type was $10.65 \mathrm{~mm}$, between carina and displaced type was $6.1 \mathrm{~mm}$. There was no difference between displaced type and pig bronchus type according to distance from carina $(p=0.067)$. Supernumerary type was not evaluated statistically in means of 'distance from carina' because of insufficient sample size (Table 2).

Tracheal bronchus (TB) is a congenital anomaly which originates from trachea or either main bronchus and it is directed to the upper lobe of the lung ${ }^{[3]}$ Errors in the pattern of pulmonary branching during embryonic fourth and fifth week result in defects ranging from abnormal number of pulmonary lobes or bronchial segments to the complete absence of a lung. ${ }^{[9,10]}$ Previous studies have shown that replacement of tracheal mesenchyme with that from the region of bifurcating bronchial buds stimulates ectopic tracheal budding and branching ${ }^{[9]}$ Extracellular matrix components (like collagen types IV and V, laminin, fibronectin and tenascin) and growth factors (like retinoic acid, transforming growth factor $a$ and $\beta$, epithelial growth factor, platelet-derived growth factor, insulin-like growth factor) have been implicated in the stimulation and inhibition of branching. ${ }^{[1]]}$ Also defects in the Shh, Wnt or Bmp pathway or mutations of Sox2, Nkx2.1 or Rhou can result in abnormal trachea and bronchus development. ${ }^{[12]}$ If a blind pouch protrudes from trachea like a bronchus-like projection, it is named as tracheal diverticulum. Sometimes this outgrowth may terminate in normal-appearing lung tissue, forming a tracheal lobe of the lung and named as tracheal bronchus (TB). ${ }^{[10]}$

Tracheal bronchii were previously evaluated in anatomical specimens, bronchoscopy, computed tomography studies. ${ }^{[2,5-}$ ${ }^{7]}$ In the present study we evaluated this variation on CT images which is diagnostic tool that enables proper evaluation of TB types and clear view of additional anomalies of airway tree in large patient series.

The incidence of TB reported in the literature varies in a range from $0.1 \%-2 \%$.TB accounts for $80 \%$ of the anatomical variations of airway ${ }^{[13]}$ Congenital anomalies such as pectus excavatum, tracheal stenosis, Down's syndrome may accompany TB. ${ }^{[2]}$

Doolittle et al. ${ }^{[1]}$ reported TB incidence $0.5 \%$ in their study including 1000 patients' bronchoscopy findings. Lee et al. ${ }^{[6]}$ reported incidence of TB $0.45 \%$ in bronchoscopy study performed on 673 patients. $1.9 \%$ incidence was reported by Ruiz et al. ${ }^{[13]}$ in their study including 1337 bronchoscopic examinations. Our data included CT findings of 1500 patients and the incidence was detected $0.8 \%$. Incidence of TB in our data is in consistent with the previously reported incidence range in the literature. Larger patient number is an additional value of the present study. 
TB is reported to be located about $2-6 \mathrm{~cm}$ superior to carina in the literature. ${ }^{[2,5-8]}$ In our study distance of TB from carina was analyzed within each type (Table 2). This data provides a contribution to literature. Detailed measurement provided in this study will give an idea to doctors when intubating patients and prevent adverse outcomes after intubation.

Detailed anatomical definition of this variation has critical importance for lung transplantation. Mendogni et al reported that size of bronchial orifice, distance between TB and right upper lobe bronchus are important features for proper anastomosis between recipient and donor tissues. ${ }^{[14]}$ In the present study we measured diameter of TB $5.24 \pm 1.53$. We think distance between TB and right upper lobe bronchus measured among patients with TB will provide precious contribution to literature in the following studies.

Recognizing the TB is critically important during endotracheal intubation. When the TB is occluded by the side of the tube the lobe may collapse. On the other hand when it is mistakenly intubated, over aeration may lead pneumothorax..$^{[1,15]}$ The tube itself can also migrate into tracheal bronchus and cause atelectasis. ${ }^{[16]}$ Anesthesiologists should spend special care during intubation of patients with TB. The position of tip of the endotracheal tube must be kept in the mid to proximal trachea. ${ }^{[1,15]}$

Distal placement of the endotracheal tube occurs in 3.7$10.7 \%$ of intubations. Accidentally displaced endotracheal tube may result in a drop in oxygen saturation in patients with tracheal bronchus. Although TB is a rare congenital anomaly a physician may encounter this anomaly several times a year. Obstruction of TB due to distal placement of endotracheal tube is a conceivable problem. ${ }^{[17,18]}$

Patients with TB incidentally detected on CT images should be informed to prevent probable anesthesia complications in future. 'One lung ventilation' is an anesthesia procedure commonly performed in thoracic surgery and video assisted thoracoscopic surgery.

Anesthesiologists may face problems in patients with undiagnosed TB when isolating lung in these types of surgical modalities. Detailed bronchoscopic examination before thoracic surgery provides sufficient information for proper anesthesia. ${ }^{[6]}$ This study will contribute to literature and will serve data of incidence to anesthesiologists in our country.

Lai et al. ${ }^{[18]}$ suggest that TB is an asymptomatic entity which is incidentally diagnosed on CT. They also argue that TB causes recurrent infections and respiratory distress especially in children. Oi et al. ${ }^{[5]}$ suggested that individuals with TB have higher risk of recurrent local infections, cough and acute respiratory distress than healthy ones. Incidental or accidental obstruction of TB in intensive care units or during general anesthesia may cause pneumothorax, atelectasis, post obstructive pneumonia or respiratory failure. TB which is an asymptomatic anatomical variation may cause serious adverse outcomes in certain conditions. Pulmonologists, thoracic surgeons, intensivists and anesthesiologists should keep this anomaly in mind.
Our study has some limitations. TB was found more frequently in women than in men in the present study but larger patient series are required to claim this idea statistically. Supernumerary type was not evaluated statistically in means of diameter because of insufficient sample size. Distance of supernumerary type from carina was not also evaluated statistically because of insufficient sample size. We predict further studies with larger sample size will enlighten these missing points in the present study.

\section{CONCLUSIONS}

Pulmonologists, thoracic surgeons, intensivists and anesthesiologists should keep this variation in mind for proper management of adverse outcomes of intubation pitfalls.

\section{ETHICAL DECLARATIONS}

Ethics Comittee Approval: Approval was received by Ankara Yıldırım Beyazıt University Education and Research Hospital Clinical Research Ethics Committee (Date: 11.09.2019, no: 92).

Informed Consent: Written informed consent was obtained from all participants who participated in this study.

Status of Peer-review: Externally peer-reviewed.

Conflict of Interest Statement: The authors have no conflicts of interest to declare.

Financial Disclosure: The authors declared that this study has received no financial support.

Author Contributions: All of the authors declare that they have all participated in the design, execution, and analysis of the paper, and that they have approved the final version.

\section{REFERENCES}

1. Doolıttle AM, Maır EA Tracheal bronchus: classification, endoscopic analysis, and airway management Otolaryngol Head Neck Surg2002;126:240-3. doi:10.1067/mhn.2002.122703.

2. Levin E, Bowling MR. Malignancy in the tracheal bronchus: A case series and review of the literature. Clin Respir J. 2018; 12:2441-2445. doi: $10.1111 /$ crj.12943.

3. Manjunatha YC, Gupta AK. Tracheal Bronchus (Pig Bronchus). Indian J Pediatr 2010; 77:1037-1038. doi: 10.1007/s12098-0100162-6.

4. Han J, Xiang H, Ridley WE, Ridley LJ. Pig bronchus. 2018 The Royal Australian and New Zealand College of Radiologists. doi:10.1111/17549485.21_12785.

5. Qi S, Zhang B, YueY, Shen J, TengY, Qian W, Wu J. Airflow in Tracheobronchial Tree of Subjects with Tracheal Bronchus Simulated Using CT Image Based Models and CFD Method. Med Syst. 2018;42(4):65. doi: 10.1007/s10916017-0879-0.

6. Lee DK, Kim YM, Kim HZ, Lim SH. Right upper lobe tracheal bronchus: anesthetic challenge in one-lung ventilated patients-A report of three casesKorean J Anesthesiol 2013; 64(5): 448-450.

7. Barbetta C,Tamburini N, Marchi I, Forini G, Papi A. True tracheal bronchus. Anaesthesia 2016; 71(7): 846. doi:10.1111/anae.13531.

8. Sindhwani G, Rawat J, Gupta M, Chandra S. Lung Cancer in "True Tracheal Bronchus" A Rare Coincidence. J Bronchol Intervent Pulmonol 2012; 19 340-342. 
9. Schoenwolf GC, Blely SB, Brauer PR, Francis-West PH. Larsen's Human Embryology, 5th Edt.(2015),Elsevier, 252-259.

10. Moore KL, Persaud TVN, Torchia MG. The Developing HumanClinically Oriented Embryology, 10th Edt.(2016), Elsevier, 195200.

11. Carlson BM, Human Embryology and Developmental Biology, 5th Edt. (2014), Elsevier, 359-362.

12. Snowball J, Ambalavanan M, Whitsett J, Sinner D. Endodermal Wnt signaling is required for tracheal cartilage formation. Dev. Biol. 2015; 405(1): 56-70. doi: 10.1016/j.ydbio.2015.06.009.

13. Ruiz EP, Aguilera PC, Valdivielso AI, Cárdenas SS, García YM, Frías JP.Tracheal bronchus diagnosed in children undergoing flexible bronchoscopy. Paediatric Respiratory Reviews 2018;28:26-30.

14. Mendognia P, Tosia D, Rossoa L, Palleschia A, Righia I, Montolia M, Marioloa AV, Nosottia M. Lung Transplant From Donor With Tracheal Bronchus: Case Report and Literature Review. Transplant Proc. 2019; 51(1): 239-241.

15. Jain D, Bhardwaj N, Pareek A, Parikh B. Tracheal bronchus: an unusual cause of difficult ventilation. Can J Anaesth. 2017; 64(9): 979-980. doi: 10.1007/s12630-017-0919-8.

16. Wong F, Detterbeck F, Kurup V. Airway Management in Patients with Tracheal Bronchus. Images in Anesthesiology. Anesthesiology, 2016;125(2): 395. doi:10.1097/ aln.0000000000001019.

17. Ho AK, Ho AMH, Mizubuti GB. Blockage of the tracheal bronchus: effects on blood oxygen content, partial pressure of oxygen, and intrapulmonary shunt. Adv Physiol Educ 2018; 42: 383-6, doi:10.1152/advan.00017.2018.

18. Lai KM, Hsieh MH, Lama F, Chen CY, Chen TL, Chang CC. Anesthesia for patients with tracheal bronchus. Asian Journal of Anesthesiology 2017; 55: 87-8. 